\title{
Nonuniform response of the major surface currents in the Nordic Seas to insolation forcing: Implications for the Holocene climate variability
}

\author{
C. Andersen ${ }^{1}$ and N. Koç \\ Norwegian Polar Institute, Tromsø, Norway
}

\section{A. Jennings and J. T. Andrews}

INSTAAR and Department of Geological Sciences, Box 450, University of Colorado, Boulder, Colorado, USA

Received 19 December 2002; revised 20 May 2003; accepted 8 October 2003; published 6 April 2004.

[1] High-resolution sediment cores from the Vøring Plateau, the North Iceland shelf, and the East Greenland shelf have been studied to investigate the stability of major surface currents in the Nordic Seas during the Holocene. Results from diatom assemblages and reconstructed sea-surface temperatures (SSTs) indicate a division of the Holocene into three periods: the Holocene Climate Optimum (9500-6500 calendar (cal) years BP), the Holocene Transition Period (6500-3000 cal years BP) and the Cool Late Holocene Period (3000-0 cal years BP). The overall climate development is in step with the decreasing insolation on the Northern Hemisphere, but regional differences occur regarding both timing and magnitude of SST changes. Sites under the direct influence of the Norwegian Atlantic Current and the Irminger Current indicate SST cooling of $4-5^{\circ} \mathrm{C}$ from early Holocene to present, compared to $2^{\circ} \mathrm{C}$ recorded under the East Greenland Current. Superimposed on the general Holocene cooling trend, there is a high-frequency SST variability, which is in the order of $1-1.5^{\circ} \mathrm{C}$ for the Vøring Plateau and the East Greenland shelf and $2.5-3^{\circ} \mathrm{C}$ on the North Iceland shelf. INDEX TERMS: 4267 Oceanography: General: Paleoceanography; 1620 Global Change: Climate dynamics (3309); 3344 Meteorology and Atmospheric Dynamics: Paleoclimatology; KEYWORDS: Nordic Seas, Holocene, sea-surface temperatures

Citation: Andersen, C., N. Koç, A. Jennings, and J. T. Andrews (2004), Nonuniform response of the major surface currents in the Nordic Seas to insolation forcing: Implications for the Holocene climate variability, Paleoceanography, 19, PA2003,

doi:10.1029/2002PA000873.

\section{Introduction}

[2] The Nordic Seas, being a gateway for transport of oceanic heat flux to northern latitudes and a transmitter of freshwater out of the Arctic region, is a sensitive area regarding climate changes. Major surface currents in the Nordic Seas are the Norwegian Atlantic Current (NwAC), the Irminger Current (IC) and the East Greenland Current (EGC). Through their transport of heat, salt and sea ice these currents can alter the "thermohaline circulation" (the label of North Atlantic ocean circulation is discussed in the work of Wunsch [2002]) in the Nordic Seas and, as a result, modify northern European climate [e.g., Dickson et al., 1988; Sarnthein et al., 1992; Overpeck et al., 1997; Stocker and Schmittner, 1997]. Recent observations of the propagation of salt anomalies have shown that the ocean circulation can be highly vulnerable to changes in the thermohaline structure, causing among other things an east-west movement of the temperature structure [Dickson et al., 1988]. Variability in the "thermohaline circulation"

\footnotetext{
${ }^{1}$ Also at Department of Earth Science, University of Bergen, Bergen, Norway.

Copyright 2004 by the American Geophysical Union. 0883-8305/04/2002PA000873
}

can further effect the convective formation of deep water in the Nordic Seas, and thereby the global ocean circulation. Several dramatic reorganizations in the Nordic Seas ocean circulation have occurred during the last glacial and deglacial period [e.g., Koç and Jansen, 1992; Lehman and Keigwin, 1992; Sarnthein et al., 1992; Koç and Jansen, 1994; Fronval et al., 1995; Haflidason et al., 1995; Hald and Hagen, 1998] as well as changes in the surface ocean circulation during the Holocene [Koç et al., 1993; Bauch and Weinelt, 1997; Bond et al., 1997; Hald and Aspeli, 1997; Jennings et al., 2002; Jiang et al., 2002]. Thus the Nordic Seas is frequently being evaluated on the subject of its stability.

[3] Paleoclimatic investigations in the Nordic Seas [Koç et al., 1993] have shown that during the major climatic improvement after the Younger Dryas, a northwestward retreat of the sea ice and the polar front, and an increasing inflow of Atlantic water (AW) resulted in the early Holocene being warmer than the present. A cooling trend for the second half of the Holocene followed and surface waters approached conditions similar to those of the present. This pattern is consistent with other Holocene climate reconstructions and models [Williams, 1993; Kerwin et al., 1999; Eiriksson et al., 2000; Jennings et al., 2002; Andrews and Giraudeau, 2003]. Owing to the close coupling between the ocean and atmosphere, the insolation has been pointed out 


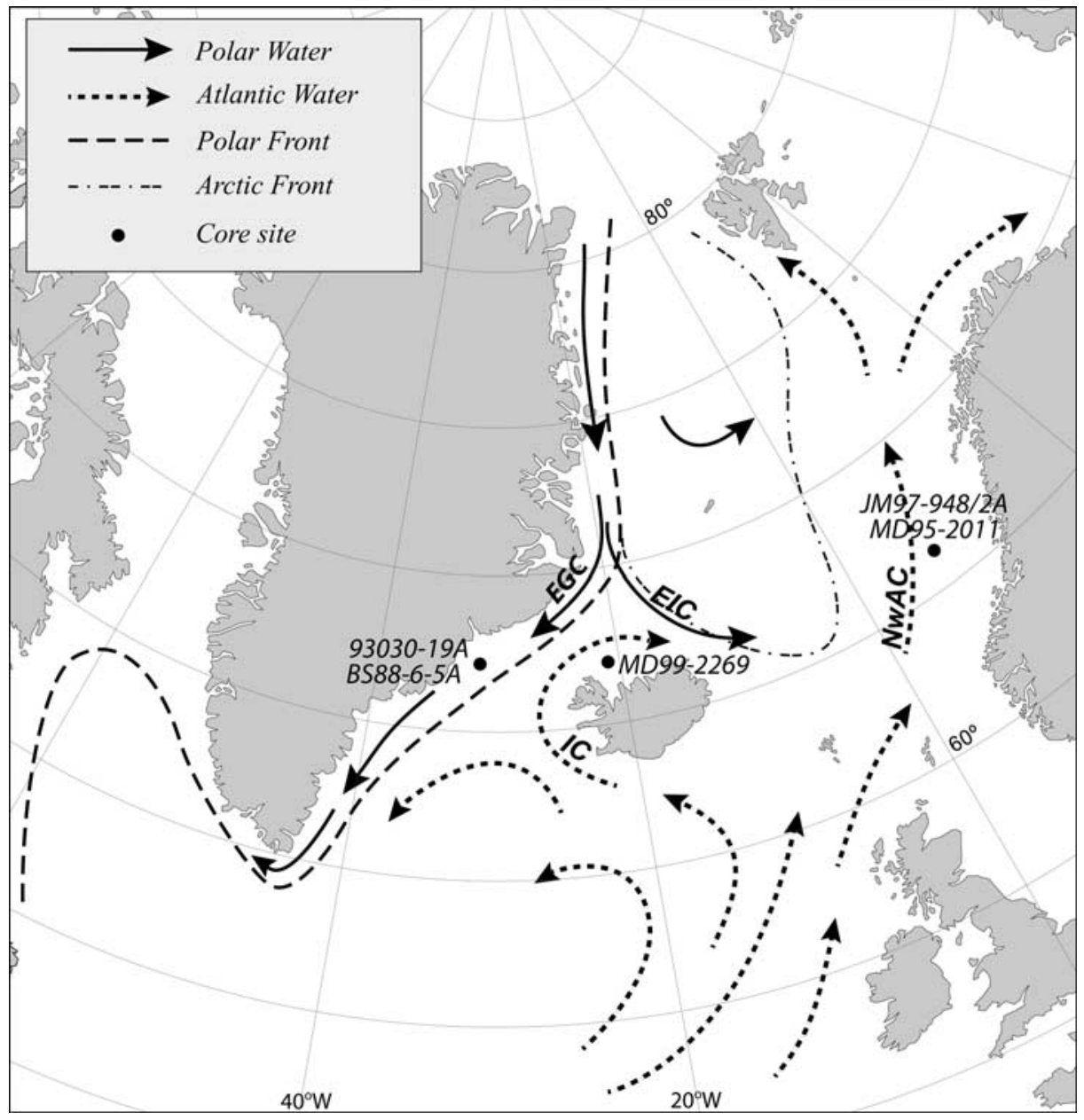

Figure 1. Location map that show the main surface circulation in the Nordic Seas and the core locations. NwAC, Norwegian Atlantic Current; IC, Irminger Current; EGC, East Greenland Current; EIC, East Icelandic Current.

as an external trigger to oceanic variability [Imbrie et al., 1989; Mayewski et al., 1997].

[4] In this study we investigate the Holocene record of sediment cores from the high accumulation areas of the Vøring Plateau, North Iceland shelf and East Greenland shelf. These are key localities to study the centennial-scale variability of the NwAC, the IC and the EGC through time. We have reconstructed past sea-surface temperatures (SSTs) based on fossil diatom assemblages from five deep-sea cores underlying these major currents. By choosing areas with high sedimentation rates, as well as methods that are able to resolve rapid and relatively low amplitude variability, we aim to generate SST time series of century-scale resolution for the Holocene. Furthermore, we wish to focus on the effects of changing insolation on the stability of the different surface currents.

\section{Physical Settings}

[5] The main elements driving the surface water conditions in the Nordic Seas are the inflow of warm AW and the outflow of cold polar water (PW) (Figure 1). Inflowing warm water in the east contributes warmth and moisture to western Europe, while the outflowing cold waters in the west control East Greenland temperatures and sea-ice extent along the East Greenland margin [Hopkins, 1991].

[6] The major branch of the AW entering the Nordic Seas is the NwAC, which is the northern branch of the North Atlantic Drift. Flowing through the Faeroe-Shetland Channel, the NwAC carries warm, saline water along the continental slope off the Norwegian coast. The NwAC has summer temperatures between $6-10^{\circ} \mathrm{C}$, and a salinity content of at least 35\% [Johannessen, 1986]. A less pronounced inflow of warm AW into the Nordic Seas is the IC. The IC separates into two branches west of Iceland, where most of it turns southwest. A smaller branch continues northward and flows around Iceland through eastern Denmark Strait [Stefánsson, 1962]. Hydrographical characteristics of this current are to a large degree similar to those of the NwAC.

[7] The EGC carries PW and sea ice southward from the Arctic, along the eastern continental margin of Greenland and out through western Denmark Strait. Generally, PW has salinities of less than $34.5 \%$ and temperatures generally below $0^{\circ} \mathrm{C}$ [Hopkins, 1991]. However, the PW layer is thin 
Table 1. Core Locations, Water Depths, Core Types and Lengths ${ }^{\mathrm{a}}$

\begin{tabular}{|c|c|c|c|c|c|}
\hline \multirow[b]{2}{*}{ Core } & \multicolumn{2}{|c|}{ Position } & \multirow{2}{*}{$\begin{array}{c}\text { Water } \\
\text { Depth, } \\
\text { m }\end{array}$} & \multirow{2}{*}{$\begin{array}{l}\text { Core } \\
\text { Type }\end{array}$} & \multirow{2}{*}{$\begin{array}{c}\text { Core } \\
\text { Length, } \\
\mathrm{cm}\end{array}$} \\
\hline & Latitude & Longitude & & & \\
\hline HU93030-19A & $67^{\circ} 08.73 \mathrm{~N}$ & $30^{\circ} 49.34 \mathrm{~W}$ & 713 & $\mathrm{BC}$ & 60 \\
\hline BS88-06-5A & $67^{\circ} 07.54 \mathrm{~N}$ & $30^{\circ} 54.26 \mathrm{~W}$ & 707 & $\mathrm{GC}$ & 75 \\
\hline MD99-2269 & $66^{\circ} 37.53 \mathrm{~N}$ & $20^{\circ} 51.16 \mathrm{~W}$ & 365 & $\mathrm{CC}$ & 2544 \\
\hline JM97-948/2A & $66^{\circ} 58.18 \mathrm{~N}$ & $07^{\circ} 38.36 \mathrm{E}$ & 1020 & $\mathrm{BC}$ & 31 \\
\hline MD95-2011 & $66^{\circ} 58.18 \mathrm{~N}$ & $07^{\circ} 38.36 \mathrm{E}$ & 1048 & $\mathrm{CC}$ & 1749 \\
\hline
\end{tabular}

${ }^{\mathrm{a}}$ Abbreviations are as follows: $\mathrm{BC}$, box core; $\mathrm{GC}$, gravity core; $\mathrm{CC}$, calypso core.

and quite strongly stratified, and during summer surface temperatures of $3-5^{\circ} \mathrm{C}$ can be reached [Swift, 1986]. A branch of the EGC forms the East Iceland Current (EIC), which transports polar water eastward into the Iceland Sea when it flows southeast along the continental slope northeast of Iceland [Swift, 1986]. Besides having the EGC as a main source, the EIC also partly derives from the counterclockwise gyre in the Iceland Sea. Being a variable surface current, fluctuating with seasons, its water masses sometimes reach the North Iceland shelf [Stefánsson, 1962; Eiríksson et al., 2000].

\section{Material and Methods}

[8] Sediment cores were collected from the Vøring Plateau, the North Iceland shelf and the East Greenland shelf (Figure 1). From the investigated sites, a total of 5 cores have been raised (Table 1). The boxcore (JM97-948/2A) from the inner Vøring Plateau was cored during a cruise with the Norwegian research vessel Jan Mayen. The giant calypso core (MD95-2011) was recovered during the IMAGES MD 101 cruise and compiled with the boxcore to make a composite record (CR) (hereafter referred to as CR 948/2011) for the last 10,000 years. The boxcore was continuously subsampled and investigated in $2.5 \mathrm{~cm}$ intervals and sediment samples were taken from the piston core at $5 \mathrm{~cm}$ intervals. Different statistical methods (Modern Analog Technique (MAT), Weighted Averaging Partial Least Squares (WA-PLS), and the Imbrie-Kipp Method (IKM)) have been performed and presented for the Vøring Plateau site for the interval representing 2000-12,000 calendar years before present (cal years BP) in the work of Birks and Koç [2002]. WA-PLS and the IKM produced very similar SST reconstructions, whereas the MAT failed to reconstruct the low amplitude variability. The IKM is being used in this paper.

[9] During the international IMAGES V Cruise in 1999, the giant calypso core MD99-2269 was collected [Andrews et al., 2003]. The core site is the Húnaflói Trough off the North Iceland shelf. Analyses were performed every $10 \mathrm{~cm}$ down to $475 \mathrm{~cm}$, and at intervals of about 20 to $30 \mathrm{~cm}$ between $475-2530 \mathrm{~cm}$.

[10] One box core (HU93030-19A) collected on the Canadian CSS Hudson, and one gravity core (BS88-065A) taken with the Icelandic research vessel Bjarni Saemundsson, was investigated from the Kangerdlugssuaq Trough on the East Greenland shelf. Qualitative diatom analyses have previously been performed on the BS88-06-
5A [Williams, 1993; Williams et al., 1995] at $5 \mathrm{~cm}$ resolution. We expanded this record for quantitative analyses with an adjacent boxcore in order to cover the most recent centuries and resampled it at a higher resolution. Boxcore HU93030-19A was investigated every $\mathrm{cm}$ from $0-10 \mathrm{~cm}$ and every other $\mathrm{cm}$ between $10-60 \mathrm{~cm}$. The gravity core was resampled every $0.5 \mathrm{~cm}$ from $0-30 \mathrm{~cm}$ and every $\mathrm{cm}$ from $30-75 \mathrm{~cm}$. The two cores were compiled to a continuous record, hereafter referred to as CR 19/5.

[11] We have used transfer functions based on diatom assemblages to reconstruct SSTs throughout the Holocene. Marine planktonic diatoms are single-celled siliceous phytoplankton, which are dependent on light for photosynthesis. Therefore they live in the uppermost surface water masses $(0-50 \mathrm{~m})$. Diatoms have been proven to be an excellent paleoclimatic tool in the Nordic Seas for several reasons [Koç and Schrader, 1990; Koç and Jansen, 1992; Koç et al., 1993]. The production and diversity of diatoms are high in Arctic and sub-Arctic regions, and especially in the vicinity of the sea ice margin [Smith et al., 1987]. They show good analogue relations to modern oceanic conditions and are linearly related to sea-surface temperature $[K o c ̧$ and Schrader, 1990; Williams, 1993]. High diversity of diatoms in polar and Arctic environments, make them one of the foremost tools available for paleoclimatic reconstructions of the sea ice margin, oceanic fronts, distribution of water masses and quantitative estimates of past SSTs in the Nordic Seas [Koç and Schrader, 1990].

[12] Before the diatom samples were analyzed, sediments were treated with acid, washed, and separated of clay by differential settling technique. For a detailed description of the method see Koç et al. [1993]. Quantitative diatom slides of cleaned samples were prepared as described by Koç and Schrader [1990]. Identification and counting of the diatom species were performed on a Leitz Orthoplan microscope with 100/1.32 magnification. Counting procedures described in the book by Schrader and Gersonde [1978] were followed. We have used the statistical procedure of IKM, which is a widely used and successful tool [e.g., Koç et al., 1993] for estimation of past SSTs [Imbrie and Kipp, 1971]. The method employs a Q-mode factor analysis, which describes the microfossil assemblage by a linear combination of several factors. The mapping of the modern distribution of diatoms in the North Atlantic and the Nordic Seas is expanded from the original work of Koç and Schrader [1990] to factor analysis of 52 species from 139 surface samples.

[13] Eight different factors defined by specific diatom assemblages were established and named according to their relation to modern surface hydrography (Figures $2 \mathrm{a}-2 \mathrm{~h}$ ). These factors are: the Arctic Greenland Assemblage (factor 1), which mirror Arctic water masses and has its highest factor loadings in the Greenland Sea (Figure 2a); the North Atlantic Assemblage (factor 2), which reflects the influence of the warm North Atlantic water masses (Figure 2b); the sub-Arctic Assemblage (factor 3), which has its highest loadings in areas of mixture between Arctic waters and Atlantic waters, both northeast and southwest of Iceland (Figure 2c). The factor can be used as an indicator of warm waters from a returning loop of the IC; the Norwegian Atlantic Current Assemblage (factor 4) that 

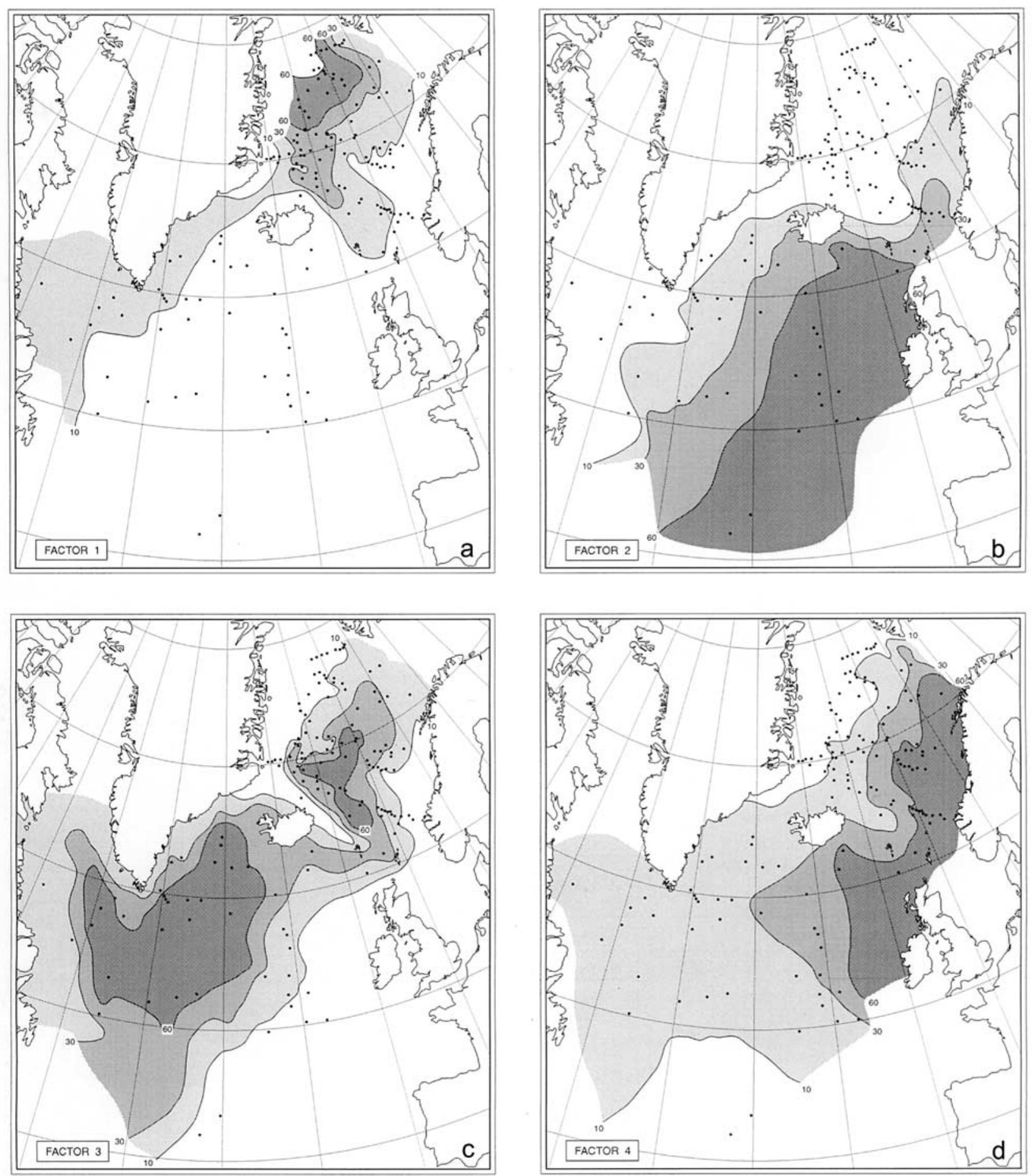

Figure 2. The modern geographic distribution and maximum factor loadings (*100) of (a) the Arctic Greenland Assemblage (factor 1), (b) the North Atlantic Assemblage (factor 2), (c) the sub-Arctic Assemblage (factor 3), (d) the Norwegian Atlantic Current Assemblage (factor 4), (e) the Sea Ice Assemblage (factor 5), (f) the Arctic Assemblage (factor 6), (g) the east and west Greenland Current Assemblage (factor 7), and (h) the Mixed Water Masses Assemblage (factor 8). 

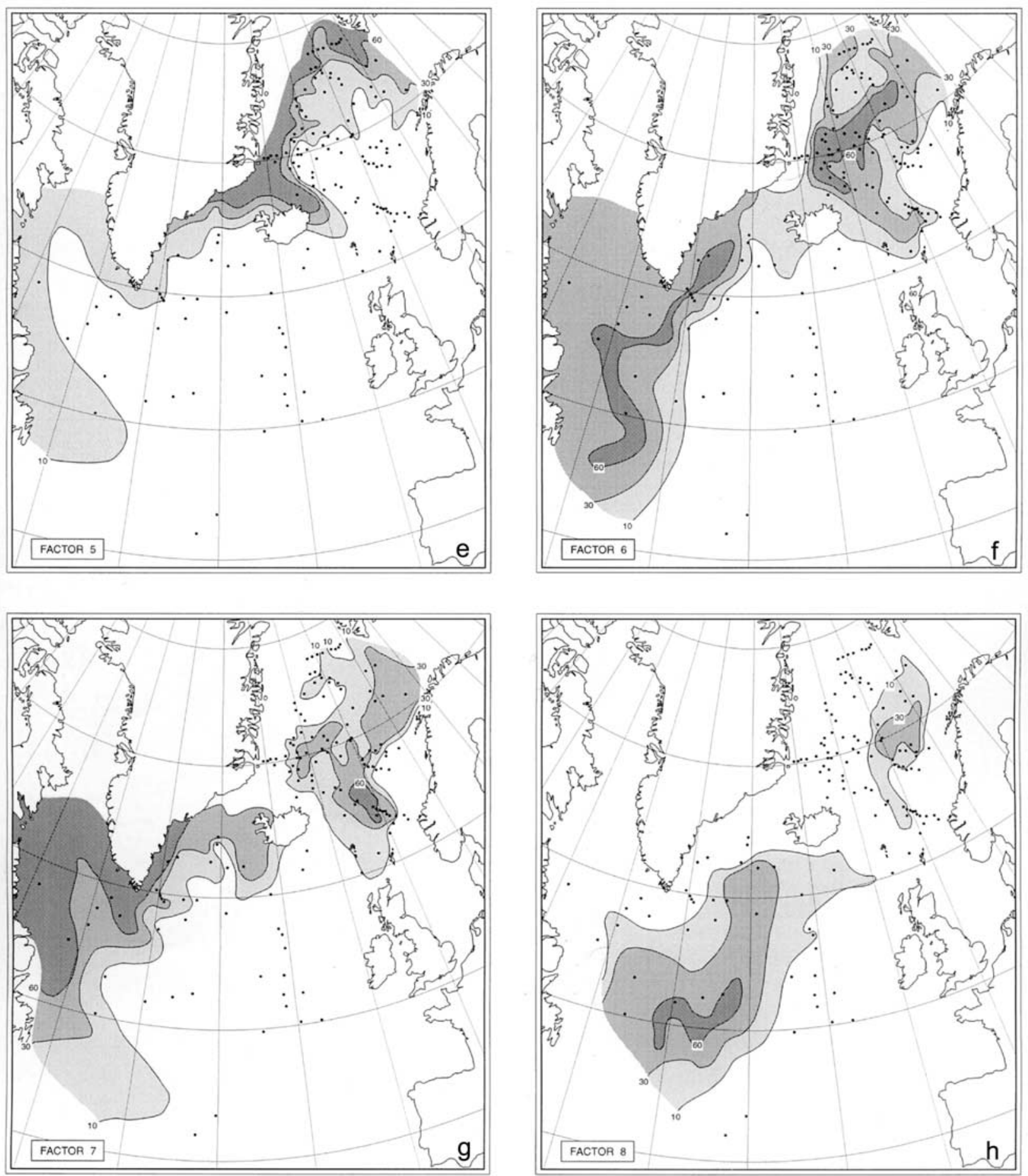

Figure 2. (continued)

can be used as an indicator of the NwAC (Figure 2d); the Sea Ice Assemblage (factor 5), which corresponds to the spring sea ice limit (Figure 2e); the Arctic Assemblage (factor 6), which has its highest loadings in waters between the polar and the Atlantic waters north of Iceland, and in an intermediate area between PW and AW southwest of Iceland (Figure 2f); the East and West Greenland Current Assem- blage (factor 7), which has its highest factor loadings under the EGC and the West Greenland Current, continuing into the Labrador Sea. A small plume of this assemblage is also seen in close vicinity to the Arctic front, west of the NwAC (Figure 2g); and finally the Mixed Water Masses Assemblage (factor 8) that has the highest loadings in a conjunction area between the Labrador Sea and the North Atlantic 
(Figure 2h). Because of their close affinity to modern hydrographic regimes these factors enable us to reconstruct details of surface current variability.

[14] The downcore diatom abundances are transformed to factors by multiplying the species abundance matrix by the core-top matrix. These downcore factors are then used in the temperature equations to calculate paleotemperatures. In our case, the IKM is based on eight components and has a root mean square error of $1.25^{\circ} \mathrm{C}$, a coefficient of determination between observed and inferred SST of 0.89, and a maximum bias of $0.92^{\circ} \mathrm{C}$.

\section{Chronology}

[15] Accelerator mass spectrometry (AMS) dating and lead $210\left({ }^{210} \mathrm{~Pb}\right)$ measurements were used to establish age models for the cores. The AMS datings were performed on foraminifera and molluscs (see Table 2 for details) and calibrated to calendar years (Table 2) using the calibration program Calib 4.3 [Stuiver and Braziunas, 1993; Stuiver et al., 1998a, 1998b]. Conventional radiocarbon ages of marine reservoirs are generally too old and an age adjustment is needed. A reservoir age correction of 400 years is included in Calib 4.3. However, the reservoir effect is not constant due to ocean circulation. This regional effect is called the delta $\mathrm{R}(\Delta \mathrm{R})$ [Stuiver and Braziunas, 1993]. Owing to considerable distance to sites where this additional reservoir effect has been calculated, $\Delta \mathrm{R}$ is set to zero for the Vøring Plateau and North Iceland shelf sites. As for the East Greenland shelf location, a 550 year reservoir age has been measured [Hjort, 1973]. Therefore a mean $\Delta \mathrm{R}$ of $140 \pm$ 45 years is added to AMS dates from this site [Stuiver and Braziunas, 1993].

[16] The establishment of age-depth models for the studied cores were done by linear interpolation between dated levels (Table 2). The age model of the Vøring Plateau boxcore is based on ${ }^{210} \mathrm{~Pb}$ and AMS dates. ${ }^{210} \mathrm{~Pb}$ measurements down to $10.25 \mathrm{~cm}$ were included in order to obtain the best linear fit to the two AMS dates from the lower half of the core. The Vedde Ash layer and 10 AMS dates in the giant calypso core, give a good age control for the composite Vøring Plateau record CR 948/2011. MD99-2269 from the North Iceland shelf is a $25 \mathrm{~m}$ long sediment core consisting of $20 \mathrm{~m}$ of Holocene. The age control of the core is based on nine AMS-dates and the Saksunarvatn tephra layer (Table 2). The age control for the East Greenland shelf composite record, CR 19/5 is based on calculations of sedimentation rates estimated from ${ }^{210} \mathrm{~Pb}$ measurements [Smith et al., 2002] and linear interpolation between AMS dates. Owing to insufficient amount of carbonate in the sediment samples, the East Greenland shelf boxcore chronology is solely based on calculations of sedimentation rates from ${ }^{210} \mathrm{~Pb}$ analysis [Smith et al., 2002]. The piston core is dated with 4 AMS dates (Table 2). The compiled East Greenland shelf record spans the last 9300 calendar years.

\section{Results}

[17] The results of the factor analysis and the estimated SSTs are shown in Figures 3 and 4. Results from the factor analysis show high communalities (generally between 0.70 and 0.90 ) and thereby give confidence to the estimated SSTs. The dots in Figure 4 indicate the modern surface temperatures over the sites, and show that predicted modern SSTs and observed modern SSTs have minor divergencies. Since the surface changes and variabilities are registered in the diatom assemblages, i.e., the factors, caution should only be pointed toward the absolute values of the estimated temperatures.

[18] Warm AW and the NwAC characterize modern surface conditions over the Vøring Plateau [e.g., Hopkins, 1991] and the past variability of warm water influx and surface water warming is reflected in the reconstructed surface temperatures. The two diatom assemblages that represent AW masses and dominate the Vøring Plateau site at different times during the Holocene are the North Atlantic Assemblage (factor 2) and the Norwegian Atlantic Current Assemblage (factor 4) (Figures 2b, 2d, and 3a).

[19] Both warm and cold surface currents influence the two western sites. The warm IC dominates the North Iceland shelf site, but a cold tongue from the EIC occasionally extends over the shelf [Malmberg, 1985]. The parallel flow of the IC and the EIC cause lateral and vertical mixing of the two water masses [Eiriksson et al., 2000]. The North Atlantic Assemblage (factor 2) reflect the amount of AW reaching the North Iceland shelf and the strength of the IC flowing around Iceland, while cold water from the EIC is reflected by the Arctic Assemblage (factor 6) (Figures 2b, $2 \mathrm{f}$, and $3 \mathrm{~b}$ ). The North Iceland shelf is also overflown by sea ice at times of strong PW influence [Malmberg, 1985], and the factor representing the presence of sea ice is the Sea Ice Assemblage (factor 5) (Figures 2e and 3b).

[20] The East Greenland shelf is dominated by sea ice and the cold EGC [Sigtryggsson, 1972; Johannessen, 1986], which is reflected by the Sea Ice Assemblage (factor 5) and the Arctic Assemblage (factor 6) respectively (Figures 2e, $2 \mathrm{f}$ and $3 \mathrm{c}$ ). However, the area can also be influenced by a returning loop of the warm IC flowing along the East Greenland shelf slope [Malmberg, 1985; Williams, 1993]. The front between the EGC and the IC is called the East Greenland Front [Johannessen, 1986] and during periods of diminishing outflow from the Arctic this front may migrate shoreward causing the IC to flow closer to the shelf [Williams, 1993]. Such a scenario would be reflected by the presence of the sub-Arctic Assemblage (factor 3) (Figures 2c and 3c).

[21] The most evident feature in the reconstructed SST time series is that the overall trend is similar in all three sites (Figures $4 \mathrm{~b}-4 \mathrm{~d}$ ). The early Holocene stands out with SSTs warmer than the estimated modern temperatures (hereafter referred to as present), as the warm diatom assemblages were dominant (Figures 3a-3c). This Holocene warm period is followed by a continuous cooling trend where the warm diatom assemblages gradually became less influential. On the basis of the characteristic features of this climatic development, we have subdivided the Holocene into three major time periods. These are: the Holocene Climate Optimum (9500-6500 cal years BP), the Holocene Transition Period (6500-3000 cal years BP) and the Cool Late Holocene Period (3000 cal years BP to present). The 
Table 2. Radiocarbon Dates Included in the Age Chronology of the Investigated Cores

\begin{tabular}{|c|c|c|c|c|}
\hline Depth, cm & Laboratory & Species/Marker/Measurement & $\begin{array}{c}{ }^{14} \mathrm{C} \text { Age } \pm \text { Standard } \\
\text { Deviation } \\
\end{array}$ & $\begin{array}{c}\text { Calibrated Age } \\
\text { BP, } 1950 \\
\end{array}$ \\
\hline \multicolumn{5}{|c|}{ Core HU93030-19 } \\
\hline 0.5 & $\mathrm{SIO}$ & ${ }^{210} \mathrm{~Pb}$ & & -43 \\
\hline 5.5 & SIO & ${ }^{210} \mathrm{~Pb}$ & & -18 \\
\hline 10.5 & SIO & ${ }^{210} \mathrm{~Pb}$ & & 7 \\
\hline 15.5 & SIO & ${ }^{210} \mathrm{~Pb}$ & & 22 \\
\hline 20.5 & SIO & ${ }^{210} \mathrm{~Pb}$ & & 57 \\
\hline 25.5 & SIO & ${ }^{210} \mathrm{~Pb}$ & & 82 \\
\hline \multicolumn{5}{|c|}{ Core BS88-06-5A } \\
\hline 2.0 & AA 4338 & benthic foraminifers & $985 \pm 50$ & 480 \\
\hline 17.0 & AA 43584 & benthic foraminifers & $3411 \pm 53$ & 3100 \\
\hline 28.0 & AA 4529 & benthic foraminifers & $5835 \pm 60$ & 6107 \\
\hline 74.25 & AA 3976 & benthic foraminifers & $8965 \pm 110$ & 9249 \\
\hline \multicolumn{5}{|c|}{ Core MD99-2269 } \\
\hline 1.0 & AA 38584 & B. glacialis & $72 \pm 37$ & Postbomb $^{a}$ \\
\hline 42.5 & CURL 5732 & A. glacialis & $675 \pm 30$ & 318 \\
\hline 131.0 & CURL 5733 & Mollusc, Macoma sp. & $1010 \pm 30$ & 588 \\
\hline 177.5 & AA 38585 & B. glacialis & $1226 \pm 25$ & 755 \\
\hline 266.0 & AA 47785 & Mollusc, Macoma sp. & $1693 \pm 42$ & 1250 \\
\hline 456.0 & AA 38586 & Mollusc, Yoldia cf. Y. myalis & $2578 \pm 48$ & 2249 \\
\hline 983.0 & AA 35175 & Gastropoda (unidentified) & $4505 \pm 50$ & 4712 \\
\hline 1171 & AA 47786 & Mollusc, Yoldiella cf. Y. lenticula & $5296 \pm 53$ & 5645 \\
\hline 1552.5 & AA 38587 & Mollusc, Yoldia cf. Y. myalis & $7749 \pm 62$ & 8219 \\
\hline 1601 & AA 51435 & Mollusc, Macoma baltica & $8084 \pm 57$ & 8522 \\
\hline 2013.0 & AA 35176 & Mollusc (unidentified) & $9265 \pm 70$ & 10,017 \\
\hline 2120.5 & & tephra horizon & Saksun. Ash & $10,180^{\mathrm{b}}$ \\
\hline 2532.0 & AA 35805 & benthic foraminifers & $10,920 \pm 85$ & 12,382 \\
\hline \multicolumn{5}{|c|}{ Core JM97-948/2A } \\
\hline 0.25 & RNL & ${ }^{210} \mathrm{~Pb}$ & & -45 \\
\hline 0.75 & RNL & ${ }^{210} \mathrm{~Pb}$ & & -41 \\
\hline 1.25 & RNL & ${ }^{210} \mathrm{~Pb}$ & & -35 \\
\hline 1.5 & RNL & ${ }^{210} \mathrm{~Pb}$ & & -30 \\
\hline 2.75 & RNL & ${ }^{210} \mathrm{~Pb}$ & & -20 \\
\hline 3.75 & RNL & ${ }^{210} \mathrm{~Pb}$ & & -10 \\
\hline 4.5 & RNL & ${ }^{210} \mathrm{~Pb}$ & & -1 \\
\hline 7.5 & RNL & ${ }^{210} \mathrm{~Pb}$ & & 18 \\
\hline 10.25 & RNL & ${ }^{210} \mathrm{~Pb}$ & & 29 \\
\hline 21.75 & KIA 4787 & $N$. pachyderma $(\mathrm{d})$ & $735 \pm 40$ & 398 \\
\hline 30.75 & KIA 4800 & N. pachyderma $(\mathrm{d})$ & $940 \pm 40$ & 529 \\
\hline \multicolumn{5}{|c|}{ Core MD95-2011 } \\
\hline 10.5 & GifA 96471 & $N$. pachyderma $(\mathrm{d})$ & $980 \pm 60$ & 551 \\
\hline 30.5 & KIA 3925 & N. pachyderma $(\mathrm{d})$ & $1040 \pm 40$ & 625 \\
\hline 47.5 & KIA 5601 & N. pachyderma $(\mathrm{d})$ & $1160 \pm 30$ & 689 \\
\hline 70.5 & KIA 3926 & N. pachyderma (d) & $1460 \pm 50$ & 987 \\
\hline 89.5 & KIA 6286 & $N$. pachyderma $(\mathrm{d})$ & $1590 \pm 50$ & 1159 \\
\hline 154.0 & KIA 6287 & N. pachyderma $(\mathrm{d})$ & $2335 \pm 25$ & 1942 \\
\hline 170.5 & GifA 96472 & $N$. pachyderma $(\mathrm{d})$ & $2620 \pm 60$ & 2309 \\
\hline 269.5 & KIA 10011 & N. pachyderma $(\mathrm{d})$ & $3820 \pm 35$ & 3763 \\
\hline 320.5 & KIA 463 & N. pachyderma $(\mathrm{d})$ & $4330 \pm 50$ & 4434 \\
\hline 520.5 & KIA 464 & N. pachyderma $(\mathrm{d})$ & $7260 \pm 60$ & 7697 \\
\hline 709.5 & & tephra horizon & Vedde Ash & $11,980^{\mathrm{b}}$ \\
\hline
\end{tabular}

${ }^{\mathrm{a}}$ Postbomb radiocarbon age means that it dates from the last $10-30$ years and calibrated age is set to -30 cal years BP (J. T. Andrews, personal communication, 2002).

${ }^{\mathrm{b}}$ Estimated tephra age from the Greenland GRIP ice core [Grönvold et al., 1995]. AMS dates were measured at University of Arizona AMS Facility (AA), INSTAAR-University of Colorado (CURL), Labor for Radiometric Dating and Isotope Research, Kiel (KIA), and Centre des Faibles Radioactivités-Gif sur Yvette (GifA). ${ }^{210} \mathrm{~PB}$ measurements were performed at Skidaway Institute of Oceanography-Georgia (SIO) and Risø National Laboratory (RNL).

results will be presented from east to west for each time period.

\subsection{Holocene Climate Optimum (9500-6500 Cal Years BP)}

[22] During the early Holocene all three sites reveal a period with higher SSTs than present. Over the Vøring
Plateau a $3^{\circ} \mathrm{C}$ SST rise from 10,000 to 9300 cal years BP marks the beginning of a Holocene Climate Optimum ( $\mathrm{HCO}$ ), with temperatures $4-5^{\circ} \mathrm{C}$ warmer than today (Figure $4 \mathrm{~b}$ ). The introduction to the $\mathrm{HCO}$ is interrupted by a minor cooling around $9000 \mathrm{cal}$ years BP. Temperatures were high and rather stable from 9000 to 6500 cal years BP. The stability and the magnitude of SSTs over the Vøring 


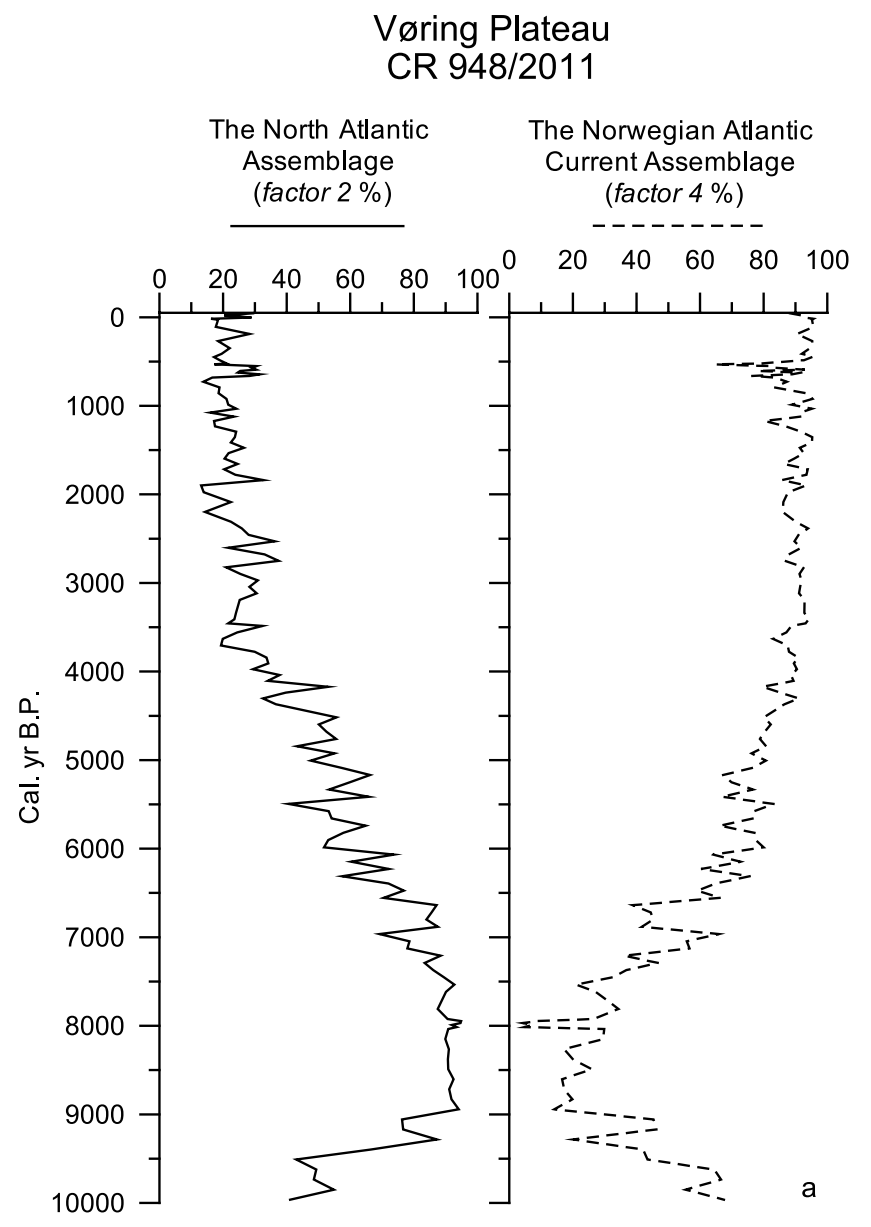

Figure 3. Significant diatom assemblages plotted (in \%) for (a) the Vøring Plateau, (b) the North Iceland shelf, and (c) the East Greenland shelf.

Plateau may imply an enhanced inflow of AW and/or a general surface water warming in the eastern part of the Nordic Seas between 9000 to 6500 cal years BP. Figure 3a shows that the diatom species which today are found in the North Atlantic, south of the Iceland-Faroe ridge (Figure 2b), dominated the site during this period.

[23] The period between 10,000 to $6500 \mathrm{cal}$ years BP on the North Iceland shelf shows highly variable, nonetheless, ameliorated SSTs at the site. From 10,000 to 9500 cal years BP SSTs were similar to present values (Figure 4c) and the Arctic Assemblage (factor 6) prevailed. A succeeding temperature rise of $5^{\circ} \mathrm{C}$ introduce the $\mathrm{HCO}$ on the North Iceland shelf reaching an early Holocene warm spike at $\sim 9000$ cal years BP. A distinct SST minimum followed at 8800 cal years BP. Within this 200 -year period, surface temperature fell by $5^{\circ} \mathrm{C}$ and punctuated the early Holocene warming. After the minimum, SSTs rose with $3-4^{\circ} \mathrm{C}$ and ameliorated surface conditions lasted until $\sim 6500$ cal years BP. In spite of the unstable character of the SSTs with several cold events and some (10\%) presence of the Sea Ice Assemblage (factor 5), the period was still $4-5^{\circ} \mathrm{C}$ warmer than the present. The warm conditions are indicative of a general surface water warming and/or an enhanced influ- ence of IC north of Iceland during the HCO. The warming variability is mirrored by the fluctuating presence of the North Atlantic Assemblage (factor 2) (Figure 3b).

[24] The Holocene record from the East Greenland shelf (CR 19/5) shows a HCO between 8500 and $\sim 6500$ cal years BP. The record starts at 9300 cal years BP with an SST decrease between 9000 and $\sim 8700$ cal years BP (Figure 4d) reflected by the dominance of the Arctic Assemblage (factor 6) and the Sea Ice Assemblage (factor 5) (Figure 3c). After this cold start temperatures gradually rose over the site and reached a HCO. During this early warm phase temperatures varied with amplitudes up to $1^{\circ} \mathrm{C}$. Around $7300-7200$, maximum temperature conditions were reached over the site. The presence of the sub-Arctic Assemblage (factor 3) over the East Greenland shelf locality reflects surface conditions warmer than today during the early Holocene (Figure 3c).

\subsection{Holocene Transition Period (6500-3000 Cal Years BP)}

[25] The results show that the 3500 years following the $\mathrm{HCO}$ was a period of gradual cooling in the Nordic Seas surface waters. Over the Vøring Plateau, SSTs dropped by $3-4^{\circ} \mathrm{C}$ between 6500 to 3000 cal years BP (Figure 4b). Throughout this Holocene Transition Period (HTP) temperatures varied by $1-1.5^{\circ} \mathrm{C}$. A prominent change in diatom assemblages occurred after 6500 and the Norwegian Atlantic Current Assemblage (factor 4) became dominant over the warmest assemblage, namely the North Atlantic Assemblage (factor 2) (Figure 3a).

[26] The period between 6500 and $3000 \mathrm{cal}$ years BP was also a time of decreasing surface temperatures over the North Iceland shelf site (Figure 4c). The SST decrease happened less uniformly than over the Vøring Plateau, showing higher amplitudes of variability $\left(2-3^{\circ} \mathrm{C}\right)$ and a slight warming from 5500 to $5000 \mathrm{cal}$ years BP. The overall temperature drop from 6500 to $3000 \mathrm{cal}$ years BP is about $4^{\circ} \mathrm{C}$. Together with the reconstructed SSTs, the increased influence of the Arctic Assemblage (factor 6) suggests a stronger influence of the EIC, although the warm IC continues to provide warm surface waters over the site (Figure $3 b$ ).

[27] The transition from HCO to late Holocene conditions is not so distinct over the East Greenland shelf (Figure 4d) as it is for the two other sites dominated by warm surface currents. A cold phase between 6500 and $6300 \mathrm{cal}$ years BP is followed by a warm peak centered around $6200 \mathrm{cal}$ years BP, which again precedes the decline in temperature toward the late Holocene SST levels. Through the period from 6500 to 3000 cal years BP SSTs vary with amplitudes of 1$1.5^{\circ} \mathrm{C}$, and the total temperature drop is $\sim 1^{\circ} \mathrm{C}$. The HTP is easier to detect in the diatom assemblages, where there is a marked change in the dominance of the Arctic Assemblage (factor 6) over the sub-Arctic Assemblage (factor 3) (Figure $3 \mathrm{c}$ ). The IC had less influence over the site during the HTP, but surface temperatures were still $2-3^{\circ} \mathrm{C}$ warmer than the modern SST.

\subsection{Cool Late Holocene Period (3000 Cal Years BP to Present)}

[28] For the last 3000 years the surface conditions over the investigated sites are characterized by lower SSTs 


\section{North Iceland shelf \\ MD99-2269}

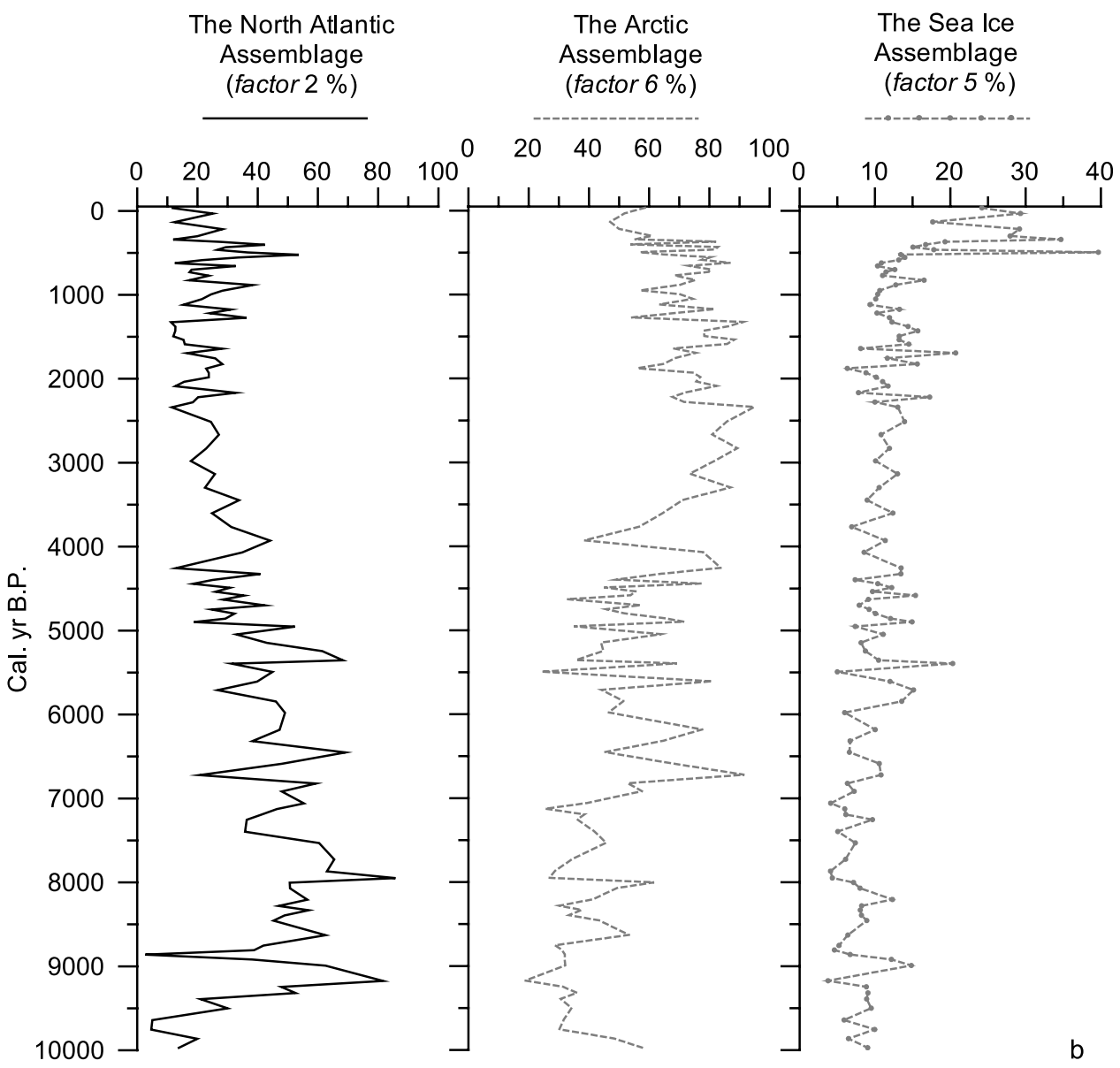

Figure 3. (continued)

compared to earlier Holocene times. During the Cool Late Holocene (CLH) SSTs varied around a mean by $1.5^{\circ} \mathrm{C}$ over the Vøring Plateau (Figure 4b). A notable feature during this period is a cold event lasting from 2350 to 1900 cal years BP with SSTs between $9.5-10^{\circ} \mathrm{C}$. An interval with similar cold surface conditions occurred between 550 and $250 \mathrm{cal}$ years BP. In a higher resolution investigation of this core this latter period is interpreted $(\mathrm{N}$. Koç et al., manuscript in preparation, 2003) to represent the marine equivalent to the "Little Ice Age" [Porter, 1986; Grove, 1988; Bradley and Jones, 1993]. During the CLH SSTs were $4-5^{\circ} \mathrm{C}$ lower than the $\mathrm{HCO}$, which is reflected by the low occurrence of the North Atlantic Assemblage (factor 2) (Figure 3a).

[29] The CLH on the North Iceland shelf is characterized by low SSTs relative to the earlier Holocene temperature levels (Figure 4c). Between 3000 and 500 cal years BP SSTs fluctuated with amplitudes of $1-2^{\circ} \mathrm{C}$. A small CLH temperature maximum around 550 cal years BP preceded a $2{ }^{\circ} \mathrm{C}$ decrease in SSTs and a SST minimum for the last 10,000 years over the site was reached at 300 cal years BP. The temperature minimum coincides with an increase in the Sea Ice Assemblage (factor 5), which points to a stronger PW influence via the EIC.
[30] The late Holocene SSTs on the East Greenland shelf are generally colder than the previous periods. Three prominent cold events took place during the CLH at this site (Figure 4d). The first cooling from 2400 to 2000 cal years BP was introduced by a $1.5^{\circ} \mathrm{C}$ temperature drop starting at 3000 cal years BP which culminated in an SST low around 2100 cal years BP. The second cooling occurred around 300 cal years $\mathrm{BP}$ and preceded a rapid warming, where SSTs rose with more than $1.5^{\circ} \mathrm{C}$ within 70 years. The third cooling took place in the second half of the last century. Until the last three centuries, SST variability at this site has been $1^{\circ} \mathrm{C}$, while SSTs varied with amplitudes of $1.5-2^{\circ} \mathrm{C}$ during the last 300 years. The Sea Ice Assemblage (factor 5) started to increase after 2400 cal years BP and was especially strong during the last three centuries indicating that the influence of the EGC increased rapidly (Figure 3c).

\section{Discussion}

[31] Our SST reconstructions show that the general Holocene climate of the Nordic Seas is characterized by an early warming followed by a gradual cooling toward the present as has been recognized in other marine records from 


\section{East Greenland shelf CR 19/5}

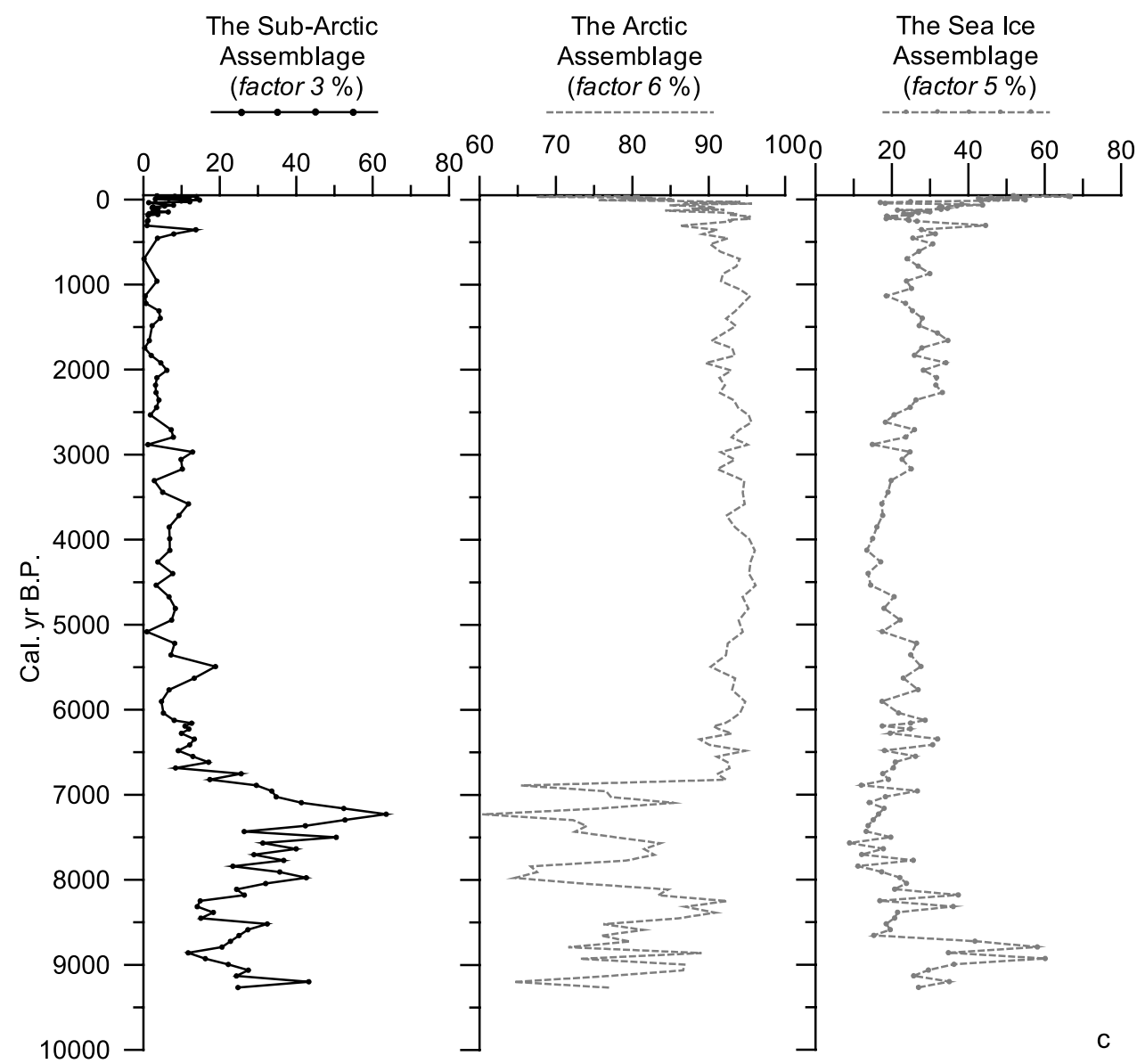

Figure 3. (continued)

the region [Koç et al., 1993; Williams, 1993; Bauch et al., 2001; Klitgaard-Kristensen et al., 2001; Jennings et al., 2002; Andrews and Giraudeau, 2003]. This cooling trend is in step with the decreasing Northern Hemisphere high latitude insolation since the early Holocene. As the summer insolation decreased by $46 \mathrm{~W} / \mathrm{m}^{2}$ at $65^{\circ} \mathrm{N}$ during the Holocene (Figure 4a) [Berger, 1978; Crucifix et al., 2002], surface conditions deteriorated. All three sites follow the insolation curve (Figures $4 \mathrm{a}-4 \mathrm{~d}$ ), indicating a strong orbital driven impact on the Holocene climate evolution as previously proposed [Bradley, 1990; Koç and Jansen, 1992; Koç and Jansen, 1994; Andrews et al., 1997].

[32] There are, nevertheless, regional differences in the timing and duration of the $\mathrm{HCO}$ and the magnitudes of surface variability indicating a more complex oceanic reaction to the insolation forcing. The HCO in the Nordic Seas occur almost 2000 years later than the Northern Hemisphere insolation maximum at $\sim 11,000$ cal years BP [Berger, 1978]. This lag is suggested to be the result of the remnants of the Laurentide and Scandinavian ice sheets [Koç and Jansen, 1994; Koç et al., 1996], as the location of the atmospheric jet stream entering Europe is sensitive to the size and geometry of the ice sheet [Harrison et al., 1992].

[33] An atmospheric circulation model, which simulate climatic sensitivity to changes in insolation, has shown that the Icelandic Low was located further north during the early Holocene than present and that westerly flow was stronger than present [Harrison et al., 1992]. These effects could have caused the North Atlantic Drift to carry more warm water further north [Wanner et al., 2001], hence strengthening the NwAC and the IC, as indicated by the presence of the North Atlantic Assemblage (factor 2) (Figures 3a and 3b) over the Vøring Plateau and North Iceland shelf, and by the sub-Arctic Assemblage (factor 3) on the East Greenland shelf (Figure 3c). This strengthening of the AW may be the high-latitude ocean feedback that is postulated by models to explain the enhanced high-latitude summer warming over the Northern Hemisphere during the early Holocene [Kerwin et al., 1999]. A stronger AW influence into the Nordic Seas during the HCO is recorded in several archives [Koç and Jansen, 1992; Koç et al., 1993; Jennings et al., 2000; Andrews et al., 1997; Klitgaard-Kristensen et al., 2001; this study]. Our results show that the enhanced inflow 


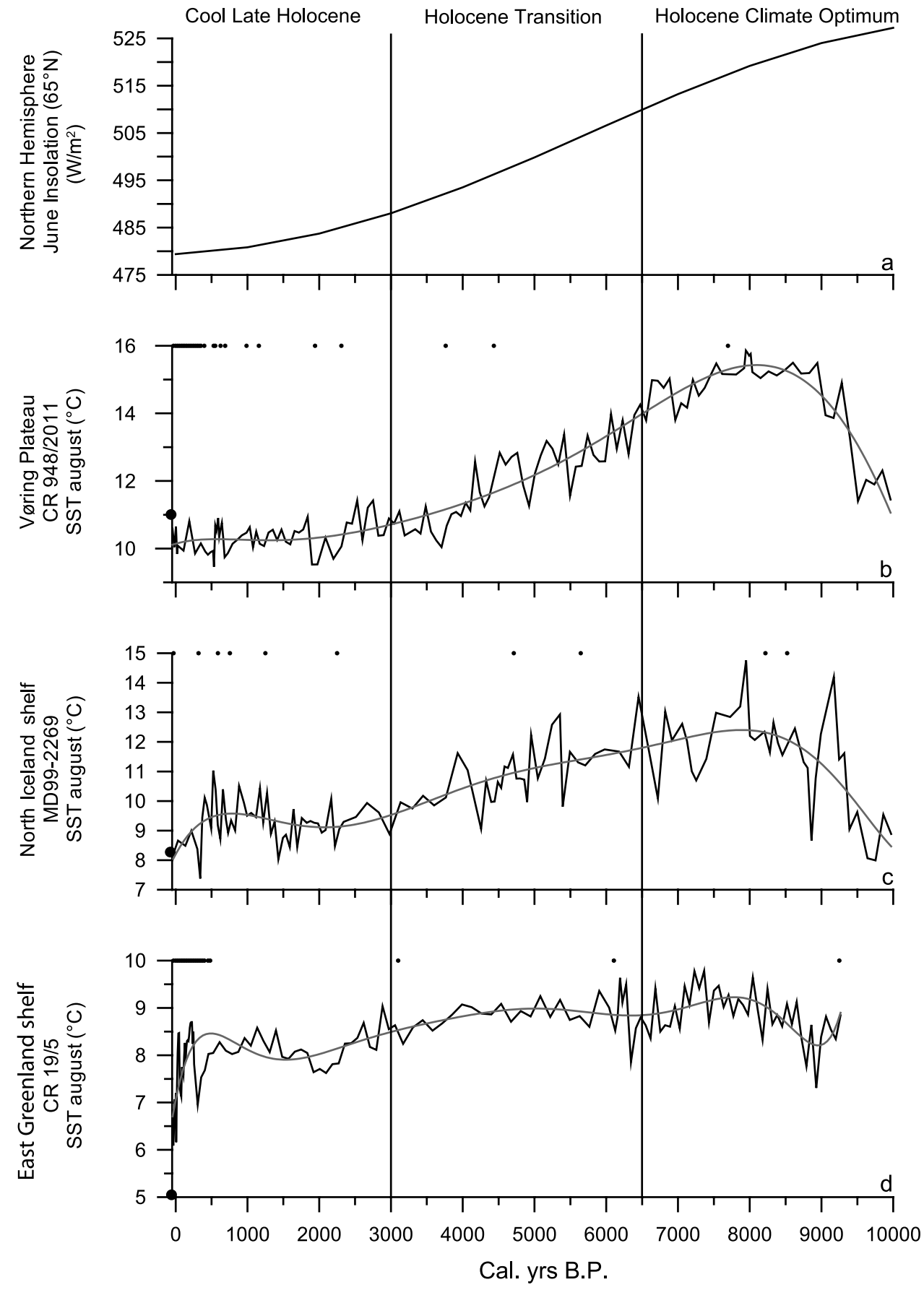

Figure 4. (a) Northern Hemisphere insolation [Berger, 1978] plotted against (b, c, and d) reconstructed SSTs for the studied sites. Results are presented in calendar years BP scale. The polynomial fit is plotted for all three curves together with the levels of ${ }^{210} \mathrm{~Pb}$ measurements and AMS-dates, marked as black dots on the figures. Large dots show the observed modern surface temperatures at the sites.

of AW resulted in warm and stable surface conditions over the Vøring Plateau with SSTs varying with amplitudes of $1-1.5^{\circ} \mathrm{C}$. The $\mathrm{HCO}$ is also found in the alkenone reconstructed SSTs from the same site [Calvo et al., 2002], although reported to occur 500 years later than that recorded in the diatoms. The effects of the early Holocene surface oceanic temperature increase are also recognized in terres- trial records where evidence points to the disappearance of several Scandinavian glaciers during this period [Karlén, 1988; Nesje and Kvamme, 1991; Nesje and Dahl, 1993]. The influence of the AW on the North Iceland shelf is recorded with the increasing presence of the North Atlantic Assemblage (factor 2). This is consistent with evidence of a strengthened IC seen in qualitative foraminiferal [Eiriksson 
et al., 2000] and coccolith data [Andrews and Giraudeau, 2003] from this area. In addition, our quantitative SST reconstructions reveal high $\left(2-3^{\circ} \mathrm{C}\right)$ variability in surface water conditions reflecting the instability of the frontal position between the IC and the EIC. The East Greenland site, situated well within the cold EGC, also records pulses of warm surface water during the HCO. This is indicated by the sub-Arctic Assemblage (factor 3), implying the presence of AW from a returning IC loop. This coincides with the reduced ice rafting input to the East Greenland margin between 8000-6000 cal years BP [Andrews et al., 1997]. Such warm surface pulses have previously been explained as a possible shoreward movement of the IC due to a diminishing outflow from the Arctic Ocean [Williams, 1993], hence reducing the EGC along the East Greenland coast.

[34] A modern climate indicator which is closely linked to the strength of the westerly winds and hence the AW inflow into the Nordic Seas, is the North Atlantic Oscillation (NAO). The NAO index quantifies the pressure difference between the Icelandic Low and the Azores High. The degree of pressure difference enhances or weakens the North Atlantic Drift [Hurrell, 1995; Wanner et al., 2001; Hurrell and van Loon, 1997; Taylor and Stephens, 1998] and effects fluctuations in North Atlantic SSTs [Bjerknes, 1964; D'Arrigo et al., 1993]. A deep and northerly located Icelandic Low during the early Holocene [Harrison et al., 1992] could thereby imply climate conditions, which would have a positive NAO signature. Conditions similar to those of a positive NAO mode could explain the warm and stable surface conditions over the Vøring Plateau during the HCO.

[35] We observe a minor delay of HCO from the eastern Nordic Seas toward the west. The delay in HCO warming support previous studies in which the Arctic front were found to be moving time transgressively westward as the initial Holocene warming took place [Koç et al., 1993]. The $\mathrm{HCO}$ is registered in the SSTs as an almost 3000-yearlong period lasting from $\sim 9500$ to $6500 \mathrm{cal}$ years BP on the Vøring Plateau and the North Iceland shelf. In comparison, the East Greenland shelf reached its warmest condition between 8500-6500 cal years BP, 1000 years later than the other two sites. This time transgressive response to orbital forcing could be due to different inertia in the mechanisms that cause the climatic changes [Imbrie et al., 1992]. In the case of the East Greenland shelf the cause could be a later recovery of sea ice and meltwater associated with the final stages of deglaciation [Koç et al., 1993; Jennings et al., 2002] as reflected by the dominance of the Arctic Assemblage (factor 6) over the warmer subArctic Assemblage (factor 3), and increased ice rafting [Andrews et al., 1997] from 9000 to $8000 \mathrm{cal}$ years BP. In addition, the North Iceland shelf experienced a set back in the HCO warming with the marked SST minima around 8800 cal years BP. SST variability of $4-5^{\circ} \mathrm{C}$ over this exposed ocean front site also indicates that the early postdeglacial period was an highly unstable period with continuous rearrangements of surface ocean conditions.

[36] The NAO is, in addition to its correlation with the strength of the westerlies, also connected to a seesaw pattern
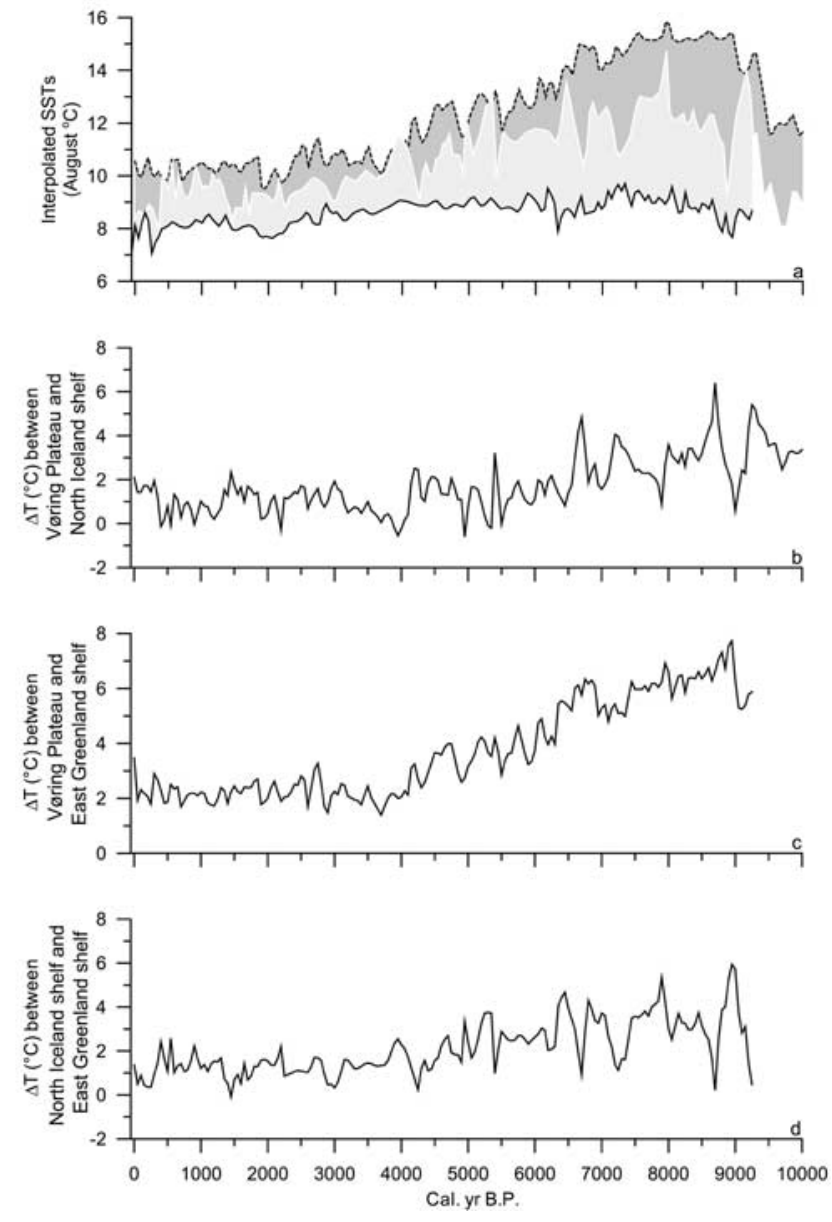

Figure 5. The three interpolated SST curves plotted together: (a) Vøring Plateau (dashed line), North Iceland shelf (white line) and East Greenland shelf (black line). (b) The temperature difference between the Vøring Plateau data set and the North Iceland shelf data set. (c) The temperature difference between the Vøring Plateau data set and the East Greenland shelf data set. (d) The temperature difference between the North Iceland shelf data set and the East Greenland shelf data set.

in the climatic response seen between the eastern and western parts of the northern North Atlantic Ocean [van Loon and Rogers, 1978; Moses et al., 1987]. During a positive NAO phase, ocean temperatures are anomalously high in the east and anomalously low in the west [Wanner et al., 2001]. Hence temperature gradients become larger. When plotting the temperature difference between our studied sites, a large temperature gradient between east and west is found during the early Holocene (Figures 5a-5d). Again, this suggests that the early Holocene climate had many similarities to those associated with the positive NAO.

[37] During the HTP our results show that the ocean heat transport to the Nordic Seas and/or the net heat exchange with the atmosphere were reduced as the amount of solar energy at $65^{\circ} \mathrm{N}$ decreased. At the same time the Arctic 
Assemblage (factor 6) became dominant over the two western sites and replaced the warmer surface waters of the HCO. A diatom record from an eastern site on the North Iceland shelf also shows a gradual decrease of warm species and a general cooling after $4600 \mathrm{cal}$ years BP [Jiang et al., 2002]. The oceanic cooling during HTP corresponds to glacial advances and reinitiation of glaciers in Scandinavia [Karlén, 1988; Nesje and Kvamme, 1991; Nesje et al., 2000], colder temperatures over Greenland [Alley and Anandakrishnan, 1995; Dahl-Jensen et al., 1998; Wagner et al., 2000] and pervasive iceberg rafting along the East Greenland coast after 6000 cal years BP [Andrews et al., 1997; Jennings et al., 2002]. An atmospheric circulation pattern with dominating northerly winds [Andrews et al., 1997], reduced heat transport into the Nordic Seas [Alley et al., 1999], and a slowdown of the "thermohaline circulation" [Bianchi and McCave, 1999] have been suggested to take place during this cooling. The magnitude of cooling registered over the two sites influenced by inflowing warm water, i.e., the Vøring Plateau and the North Iceland shelf is $4-5^{\circ} \mathrm{C}$, while the magnitude of cooling on the East Greenland shelf is only $2^{\circ} \mathrm{C}$. A moderate neoglacial cooling of $1-$ $2^{\circ} \mathrm{C}$ is also registered in melt-layers in GISP2 [Alley and Anandakrishnan, 1995]. The rather stable conditions on the East Greenland shelf indicate that the flux of the EGC has been more or less stable over the site during the HTP, while areas within or close to warm water pools showed a higher amplitude of change.

[38] The atmospheric circulation response to the decreasing summer insolation is a gradual southward displacement of the Icelandic Low and a steady decreased in the strength of the westerlies [Harrison et al., 1992]. The Holocene climatic development recorded in our cores resembles that of a steadily decreasing positive NAO signature as the negative NAO phase strengthens. During the negative mode westerlies become weaker because of smaller pressure contrast between Iceland and Azores and get a more west-east orientation [Wanner et al., 2001]. This could again cause a reduced heat transported to the north [Wanner et al., 2001]. The consequence of weaker westerlies would be reduced temperature gradients between east and west. A signal of a continuous weakening in the gradient toward 4000 cal years BP is observed in our results followed by relatively stable gradients during the late Holocene (Figures $5 \mathrm{a}-5 \mathrm{~d}$ ). This development of the Holocene in light of the NAO signature, is also recognized in SST trends between the North Atlantic, the Mediterranean Sea and the northern Red Sea [Rimbu et al., 2003] and to some extend in western Norway glacier fluctuations [Nesje et al., 2001].

[39] The surface conditions during the late Holocene are characterized by the coldest conditions during the investigated intervals at all three sites. The dominance of cold diatom assemblages (Figures $3 a-3 c$ ) indicates that the influence of the warm surface currents continued to decrease and/or the cold currents increased in strength during the last 3000 years as the insolation at $65^{\circ} \mathrm{N}$ decreased. An increased dominance of northerly winds and advances of the polar front has been suggested as causes to late Holocene cooling [Andrews et al., 1997; Jennings et al.,
2002]. This would strengthen the EGC and EIC [Jennings et al., 2002; Eiriksson et al., 2000] over the East Greenland shelf and the North Iceland shelf. Increased sea ice over these sites especially for the last 500 years support this (Figures 3b and 3c). In addition, Andrews et al. [2001] observe decrease in carbonate content on the North Iceland margin and interpret it as intrusion of PW. A modern example of a period with stronger outflowing $\mathrm{PW}$ is the Great Salinity Anomaly (GSA) in the late 1960s where outflow of PW increased due to larger flux of sea-ice through the Fram Strait [Dickson et al., 1988; Aagaard and Carmack, 1989].

[40] The few available $\delta^{13} \mathrm{C}$ records from the Norwegian Sea indicate slow deep ventilation during the early Holocene and stronger ventilation through the rest of the Holocene [Veum et al., 1992; Bianchi and McCave, 1999; Bauch et al., 2001]. During the period of low ventilation our records show high SSTs and possibly positive NAO-like conditions. The high SSTs can be explained by an increase in warm water influx and/or a warming of more stratified water masses. Reduced ventilation of deep waters does not rule out an increased AW inflow. In fact, the intensity of ocean convection is observed to co-vary with the NAO with a progressive shutdown in the vertical exchange in the Greenland Sea during the positive index [Wanner et al., 2001]. Furthermore, models of large-scale circulation schemes for the Nordic Seas also indicate that most of the inflowing AW do not participate in deep-water formation, but become part of outflowing water masses at intermediate depth [Mauritzen, 1996a, 1996b].

[41] The Holocene climate development seen in our SST records support the assumption of the Nordic Seas being forced by orbital effects. And yet, different levels of sensitivity are registered in the different current systems. This is consistent with the postulation of changes in the Nordic Seas heat pump being one of the initial responses to changes in the orbital forcing [Imbrie et al., 1992]. The regional differences superimposed on the general cooling trend are therefore most likely due to fluctuations in the ocean circulation seen as a reduction in NwAC inflow and/ or a stronger EGC. A large-scale NAO signature enveloping the Holocene can also be an explanatory factor supported by the temperature gradients through the studied period, thereby including wind strength and wind direction as causative factors. Further, the 1960s GSA phenomenon is probably not unique during the late Holocene, and similar salinity anomalies originating in the Arctic could be the trigger to some of the Holocene instabilities recorded in our cores.

\section{Conclusions}

[42] Our results show that the Nordic Seas circulation system is highly sensitive to the large-scale insolation changes as the general Holocene climate development follows closely the Northern Hemisphere insolation. Further, our reconstructions reveal a nonlinearity with regard to magnitudes and frequencies of SST changes within each current system. The second-order regional 
variability is most likely the result of interactions between processes in the Arctic and the North Atlantic causing fluctuations between warm and cold surface currents. The main conclusions from our stability study of the major surface currents in the Nordic Seas during the Holocene are:

[43] 1. The climatic development of the NwAC, IC and EGC is in step with the postglacial decrease in Northern Hemisphere high latitude insolation.

[44] 2. HCO lasted from 9500 to $6500 \mathrm{cal}$ years BP over the AW affected sites, i.e., the Vøring Plateau and the North Iceland shelf, and from 8500 to 6500 cal years BP over the site dominated by EGC, i.e., the East Greenland shelf.

[45] 3. The westward delay in $\mathrm{HCO}$ warming is due to postglacial sea ice and meltwater influence in the western area of the Nordic Seas.

[46] 4. The total SST decrease from HCO to present is $\sim 4^{\circ} \mathrm{C}$ for the NwAC and the IC, while it is $2-3^{\circ} \mathrm{C}$ for the EGC. Thus the EGC has been quite stable during the Holocene despite the insolation forcing.

[47] 5. Century-scale surface current variability for the Holocene is shown to be $1-1.5^{\circ} \mathrm{C}$ for the Vøring Plateau and East Greenland shelf, and $2.5-3{ }^{\circ} \mathrm{C}$ on the North Iceland shelf. This indicates a more unstable frontal zone between the EIC and the IC than between the EGC and the IC.

[48] 6. From the early Holocene to $4000 \mathrm{cal}$ years BP SSTs imply a positive NAO signature to the climate system with large temperature gradients between east and west.

[49] 7. After $4000 \mathrm{cal}$ years BP the temperature gradients become weaker and a gradual transition toward a negative NAO signature evolved.

[50] Acknowledgments. The research for this paper is supported by VISTA (in collaboration with Statoil), by the Norwegian Research Council through the NOClim and NORPAST projects, and the Norwegian Polar Institute. Samples were kindly provided by INSTAAR, Colorado. C. Alexander and H. Kunzendorf carried out the Lead 210 measurements. ${ }^{14} \mathrm{C}$ datings were performed at the AMS Laboratory at the Univ. of Arizona, Leibnitz Labor für Altersbestimmung und Isotopenforschung, ChristianAlbrechts-Universität, Kiel and Centre des Faibles Radioactivités, Gif sur Yvette. Helpful comments from two anonymous reviewers are acknowledged and we also express our gratitude to the journal editor, Lisa Sloan. We would also like to thank the crew and scientists on IMAGES I and V cruises in 1995 and 1999. The work of Jennings and Andrews has been supported by NSF-ESH (for the 1999 IMAGES V cruise) and subsequent work has been supported by NSF-OPP.

\section{References}

Aagaard, K., and E. C. Carmack (1989), The role of sea ice and other fresh water in the Arctic circulation, J. Geophys. Res., 94, 14,48514,498 .

Alley, R. B., and S. Anandakrishnan (1995), Variations in melt-layer frequency in the GISP2 ice core: Implications for Holocene summer temperatures in central Greenland, Ann. Glaciol., 21, 64-70.

Alley, R. B., M. Ágústdóttir, and P. J. Fawcett (1999), Ice-core evidence of Late Holocene reduction in North Atlantic Ocean heat transport, in Mechanisms of Global Climate Change at Millennial Time Scales, Geophys. Monogr. Ser., vol. 112, edited by P. U. Clark, R. S. Webb, and L. D. Keigwin, pp. 301-312, AGU, Washington, D. C.

Andrews, J. T., and J. Giraudeau (2003), Multiproxy records showing significant Holocene environmental variability: The inner N. Iceland Shelf (Húnaflói), Quat. Sci. Rev., 22, $175-$ 193.

Andrews, J. T., L. M. Smith, R. Preston, T. Cooper, and A. E. Jennings (1997), Spatial and temporal patterns of iceberg rafting (IRD) along the East Greenland margin, ca. $68^{\circ} \mathrm{N}$, over the last $14 \mathrm{cal} \mathrm{ka}, J$. Quat. Sci., $12,1-13$.

Andrews, J. T., G. Helgadottir, A. Geirsdottir, and A. E. Jennings (2001), Multicentury-scale records of carbonate (hydrographic?) variability on the N. Iceland margin over the last 5000 yrs, Quat. Res., 56, 199-206.

Andrews, J. T., J. Hardadottir, J. S. Stoner, M. E. Mann, G. B. Kristjansdottir, and N. Koc (2003), Decadal to millennial-scale periodicities in North Iceland shelf sediments over the last 12,000 cal yr: Long-term North Atlantic oceanographic variability and solar forcing, Earth Planet. Lett., 210, 453-465.

Bauch, H. A., and M. S. Weinelt (1997), Surface water changes in the Norwegian Sea during last deglacial and Holocene times, Quat. Sci. Rev., 16, 1115-1124.

Bauch, H. A., H. Erlenkeuser, R. F. Spielhagen, U. Struck, J. Matthiessen, J. Thiede, and J. Heinemeier (2001), A multiproxy reconstruction of the evolution of deep and surface waters in the sub-Arctic Nordic seas over the last 30,000 yr, Quat. Sci. Rev., 20, 659-678.

Berger, A. L. (1978), Long-term variations of caloric insolation resulting from the Earth's orbital elements, Quat. Res., 9, 139-167.

Bianchi, G. G., and I. N. McCave (1999), Holocene periodicity in North Atlantic climate and deep-ocean flow south of Iceland, Nature, 397, 515-517.

Birks, C. J. A., and N. Koç (2002), A highresolution diatom record of late-Quaternary sea-surface temperatures and oceanographic conditions from the eastern Norwegian Sea, Boreas, 31, 323-344.

Bjerknes, J. (1964), Atlantic air-sea interaction, in Advanced Studies in Geophysics, vol. 10, edited by H. E. Landsberg and J. van Mieghem, pp. $1-$ 82, Academic, San Diego, Calif.

Bond, G., W. Showers, M. Cheseby, R. Lotti, P. Almasi, P. deMenocal, P. Priore, H. Cullen, I. Hajdas, and G. Bonani (1997), A pervasive millennial-scale cycle in North Atlantic Holocene and glacial climates, Science, 278, $1257-$ 1266.

Bradley, R. S. (1990), Holocene paleoclimatology of the Queen Elizabeth Islands, Canadian high Arctic, Quat. Sci. Rev., 9, 365384.

Bradley, R. S., and P. D. Jones (1993), "Little Ice Age" summer temperature variations: Their nature and relevance to recent global warming trends, Holocene, 3, 367-376.

Calvo, E., J. Grimalt, and E. Jansen (2002), High resolution $U_{37}^{K}$ sea surface temperature reconstructions in the Norwegian Sea during the Holocene, Quat. Sci. Rev., 21, $1385-$ 1394.

Crucifix, M., M. F. Loutre, P. Tulkens, T. Fichefet, and A. Berger (2002), Climate evolution during the Holocene: A study with an Earth system model of intermediate complexity, Clim. Dyn., $19,43-60$

Dahl-Jensen, D., K. Mosegaard, N. Gundestrup, G. D. Clow, S. J. Johnsen, A. W. Hansen, and N. Balling (1998), Past temperatures directly from the Greenland Ice Sheet, Science, 282, $268-271$.

D'Arrigo, R. D., E. R. Cook, G. C. Jacoby, and K. R. Briffa (1993), NAO and sea surface temperature signatures in tree-ring records from the North Atlantic sector, Quat. Sci. Rev., 12, 431-440.

Dickson, R. R., J. Meincke, S. A. Malmberg, and A. J. Lee (1988), The "Great Salinity Anomaly" in the Northern North Atlantic 19681982, Prog. Oceanogr., 20, 103-151.

Eiríksson, J., K. L. Knudsen, H. Haflidason, and P. Henriksen (2000), Late-glacial and Holocene palaeoceanography of the North Icelandic shelf, J. Quat. Sci., 15, 23-42.

Fronval, T., E. Jansen, J. Bloemendal, and S. Johnsen (1995), Oceanic evidence for coherent fluctuations in Fennoscandian and Laurentide ice sheets on millennium timescales, Nature, 374, 443-446.

Grönvold, K., N. Oskarsson, S. J. Johnsen, H. B. Clausen, C. U. Hammer, G. Bond, and E. Bard (1995), Ash layers from Iceland in the Greenland GRIP ice core correlated with oceanic an land sediments, Earth Planet. Sci. Lett., 135, $149-155$.

Grove, J. M. (1988), The Little Ice Age, Methuen, London.

Haflidason, H., H. P. Sejrup, D. K. Kristensen, and S. Johnsen (1995), Coupled response of the late glacial climatic shifts of northwest Europe reflected in Greenland ice cores: Evidence 
from the northern North Sea, Geology, 23, $1059-1062$.

Hald, M., and R. Aspeli (1997), Rapid climatic shifts of the northern Norwegian Sea during the last deglaciation and the Holocene, Boreas, $26,15-28$.

Hald, M., and S. Hagen (1998), Early Preboreal cooling in the Nordic seas region triggered by meltwater, Geology, 26, 615-618.

Harrison, S. P., I. C. Prentice, and P. J. Bartlein (1992), Influence of insolation and glaciation on atmospheric circulation in the North Atlantic sector: Implications of general circulation model experiments for the Late Quaternary climatology of Europe, Quat. Sci. Rev., 11, $283-$ 299.

Hjort, C. (1973), A sea correction for east Greenland, Geol. Foeren. Stockholm Foerh., 95, $132-134$.

Hopkins, T. S. (1991), The GIN-Sea-A synthesis of its physical oceanography and literature review 1972-1985, Earth Sci. Rev., 30, $175-318$.

Hurrell, J. W. (1995), Decadal trends in the North Atlantic Oscillation: Regional temperatures and precipitation, Science, 269, 676679.

Hurrell, J. W., and H. van Loon (1997), Decadal variations in climate associated with the North Atlantic Oscillation, Clim. Change, 36, 301326.

Imbrie, J., and N. G. Kipp (1971), A new micropaleontological method for quantitative micropaleontology: Application to a late Pleistocene Caribbean core, in Late Cenozoic Glacial Ages, edited by K. Turekian, pp. 71-181, Yale Univ. Press, New York.

Imbrie, J., A. McIntyre, and A. Mix (1989), Oceanic response to orbital forcing in the late Quaternary: Observational and experimental strategies, in Climate and Geo-Sciences, edited by A. L. Berger, S. Schneider, and J. C. Duplessy, pp. 121-164, Kluwer Acad., New York.

Imbrie, J., et al. (1992), On the structure and origin of major glaciation cycles: 1 . Linear responses to Milankovitch forcing, Paleoceanography, 7, 701-738.

Jennings, A., J. Syvitski, L. Gerson, K. Grönvold, A. Geirsdóttir, J. Hardardóttir, J. Andrews, and S. Hagen (2000), Chronology and paleoenvironments during the late Weichselian deglaciation of the southwest Iceland shelf, Boreas, $29,167-183$.

Jennings, A., K. L. Knudsen, M. Hald, C. V. Hansen, and J. T. Andrews (2002), A midHolocene shift in Arctic sea-ice variability on the East Greenland Shelf, Holocene, 12, 4958.

Jiang, H., M. S. Seidenkrantz, K. L. Knudsen, and J. Eiríksson (2002), Late-Holocene summer sea-surface temperatures based on a diatom record from the north Icelandic shelf, Holocene, 12, 137-147.

Johannessen, O. M. (1986), Brief overview of the physical oceanography, in The Nordic Seas, edited by B. G. Hurdle, pp. 103-127, Springer-Verlag, New York.

Karlén, W. (1988), Scandinavian glacial and climatic fluctuations during the Holocene, Quat. Sci. Rev., 7, 199-209.

Kerwin, M. W., J. T. Overpeck, R. S. Webb, A. deVernal, D. H. Rind, and R. J. Healy (1999), The role of oceanic forcing in midHolocene Northern Hemisphere climatic change, Paleoceanography, 14, 200-210

Klitgaard-Kristensen, D., H. P. Sejrup, and H. Haflidason (2001), The last 18 kyr fluc- tuations in Norwegian Sea surface conditions and implications for the magnitude of climate change: Evidence from the North Sea, Paleoceanography, 16, 455-467.

Koç, N., and E. Jansen (1992), A high-resolution diatom record of the last deglaciation from the SE Norwegian Sea: Documentation of rapid climatic changes, Paleoceanography, 7, 499520.

Koç, N., and E. Jansen (1994), Response of the high-latitude Northern Hemisphere to orbital climate forcing: Evidence from the Nordic Seas, Geology, 22, 523-526.

Koç, N., and H. Schrader (1990), Surface sediment diatom distribution and Holocene paleotemperature variations in the Greenland, Iceland and Norwegian Sea, Paleoceanography, 5, 557-580.

Koc, N., E. Jansen, and H. Haflidason (1993), Paleoceanographic reconstructions of surface ocean conditions in the Greenland, Iceland and Norwegian Seas through the last $14 \mathrm{ka}$ based on diatoms, Quat. Sci. Rev., 12, 115140.

Koc, N., E. Jansen, M. Hald, and L. Labeyrie (1996), Late glacial-Holocene sea surface temperatures and gradients between the North Atlantic and the Norwegian Sea: Implication for the Nordic heat pump, in Late Quaternary Palaeoceanography of the North Atlantic Margins, Spec. Publ., vol. 111, edited by J. T. Andrews et al., pp. 177-185, Geol. Soc., Boulder, Colo.

Lehman, S. J., and L. D. Keigwin (1992), Sudden changes in North Atlantic circulation during the last deglaciation, Nature, 356, $757-$ 762.

Malmberg, S. A. (1985), The water masses between Iceland and Greenland, J. Mar. Res. Inst., 9, 127-140.

Mauritzen, C. (1996a), Production of dense overflow waters feeding the North Atlantic across the Greenland-Scotland Ridge. part 1: Evidence for a revised circulation scheme, Deep Sea Res., 43, 769-806.

Mauritzen, C. (1996b), Production of dense overflow waters feeding the North Atlantic across the Greenland-Scotland Ridge. part 2: An inverse model, Deep Sea Res., 43, $807-$ 835

Mayewski, P. A., L. D. Meeker, M. S. Twickler, S. Whitlow, Q. Yang, B. Lyons, and M. Prentice (1997), Major features and forcing of high-latitude Northern Hemisphere atmospheric circulation using a 110,000-year-long glaciochemical series, J. Geophys. Res., 102, 26,345-26,366

Moses, T., G. N. Kiladis, H. F. Diaz, and R. G. Barry (1987), Characteristics and frequency of reversals in mean sea level pressure in the North Atlantic sector and their relationship to long-term temperature trends, J. Clim., 7, 13 30.

Nesje, A., and S. O. Dahl (1993), Late glacia and Holocene glacier fluctuations and climate variations in western Norway: A review, Quat. Sci. Rev., 12, 255-261.

Nesje, A., and M. Kvamme (1991), Holocene glacier and climate variations in western Norway: Evidence for early Holocene glacier demise and multiple Neoglacial events, Geology, $19,610-612$.

Nesje, A., S. O. Dahl, C. Andersson, and J. A. Matthews (2000), The lacustrine sedimentary sequence in Sygneskardvatnet, western Norway: A continuous, high-resolution record of the Jostedalsbreen ice cap during the Holocene, Quat. Sci. Rev., 19, 1047-1065.
Nesje, A., J. A. Matthews, S. O. Dahl, M. S. Berrisford, and C. Andersson (2001), Holocene glacier fluctuations of Flatbreen and winter-precipitation changes in the Jostedalsbreen region, western Norway, based on glaciolacustrine sediment records, Holocene, 11, $267-$ 280.

Overpeck, J., et al. (1997), Arctic environmental change of the last four centuries, Science, 278 , $1251-1256$.

Porter, S. (1986), Pattern and forcing of Northern Hemisphere glacier variations during the last millennium, Quat. Res., 26, $27-$ 48

Rimbu, N., G. Lohmann, J.-H. Kim, H. W. Arz, and R. Schneider (2003), Arctic/North Atlantic Oscillation signature in Holocene sea surface temperature trends as obtained from alkenone data, Geophys. Res. Lett., 30(6), 1280, doi:10.1029/2002GL016570.

Sarnthein, M., E. Jansen, M. Arnold, J. C. Duplessy, H. Erlenkeuser, A. Flatøy, T. Veum, E. Vogelsang, and M. S. Weinelt (1992), $\delta^{18} \mathrm{O}$ time-slice reconstruction of meltwater anomalies at termination in the North Atlantic between 50 and $80^{\circ} \mathrm{N}$, in The Last Deglaciation: Absolute and Radiocarbon Chronologies, NATO ASI Ser., vol. I2, edited by E. Bard and W. S. Broecker, pp. 183-200, SpringerVerlag, New York.

Schrader, H. J., and R. Gersonde (1978), Diatoms and silicoflagellates in the eight metres section of the lower Pliocene of Capo Rossello, Utrecht Micropaleontol. Bull., 17, $129-176$.

Sigtryggsson, H. (1972), An outline of sea ice conditions in the vicinity of Iceland, Jökull, $22,1-11$.

Smith, L. M., C. Alexander, and A. E. Jennings (2002), Accumulation in east Greenland fjords and on the continental shelves adjacent to the Denmark Strait over the last century based on ${ }^{210} \mathrm{~Pb}$ geochronology, Arctic, 55, 109-122.

Smith, W. O., M. E. M. Bauman, D. L. Wilson, and L. Aletsee (1987), Phytoplankton biomass and productivity in the marginal ice zone of the Fram Strait during the summer 1984 J. Geophys. Res., 92, 6777-6786.

Stefánsson, U. (1962), North Icelandic waters, J. Mar. Res. Inst., 3, 1-269.

Stocker, T. F., and A. S. Schmittner (1997), Influence of $\mathrm{CO}_{2}$ emission rates on the stability of the thermohaline circulation, Nature, $388,862-864$

Stuiver, M., and T. F. Braziunas (1993), Modeling atmospheric ${ }^{14} \mathrm{C}$ influences and ${ }^{14} \mathrm{C}$ ages of marine samples to $10,000 \mathrm{BC}$, Radiocarbon, 35, 137-189.

Stuiver, M., P. J. Reimer, E. Bard, J. W. Beck, G. S. Burr, K. A. Hughen, B. Kromer, F. G. McCormac, J. van der Plicht, and M. Spurk (1998a), INTCAL98 radiocarbon age calibration, 24,000-0 cal B.P., Radiocarbon, 40, $1041-1083$.

Stuiver, M., P. J. Reimer, and T. F. Braziunas (1998b), High-precision radiocarbon age calibration for terrestrial and marine samples, Radiocarbon, 40, 1127-1151.

Swift, J. H. (1986), The Arctic waters, in The Nordic Seas, edited by B. G. Hurdle, pp. 129-153, Springer-Verlag, New York.

Taylor, A. H., and J. A. Stephens (1998), The North Atlantic Oscillation and the latitude of the Gulf Stream, Tellus, 50, 134142.

van Loon, H., and J. C. Rogers (1978), The seesaw in winter temperatures between 
Greenland and northern Europe. part 1: General description, Mon. Weather Rev., 106, 296-310.

Veum, T., E. Jansen, M. Arnold, I. Beyer, and J. C. Duplessy (1992), Water mass exchange between the North Atlantic and the Norwegian Sea during the past 28,000 years, Nature, 356 , $783-785$.

Wagner, B., M. Melles, J. Hahne, F. Niessen, and H.-W. Hubberten (2000), Holocene climate history of Geographical Society Ø, east Greenland-Evidence from lake sediments, Palaeogeogr. Palaeoclimatol. Palaeoecol., 160, 45-68.
Wanner, H., S. Brönniman, C. Casty, D. Gyalistras, J. Luterbacher, C. Schmutz, D. B. Stephenson, and E. Xoplaki (2001), North Atlantic Oscillation-Concepts and studies, Surv. Geophys., $22,321-382$.

Williams, K. M. (1993), Ice sheet and ocean interactions, margin of the east Greenland ice sheet (14 Ka to present): Diatom evidence, Paleoceanography, 8, 69-83.

Williams, K. M., J. T. Andrews, N. J. Weiner, and P. J. Mudie (1995), Late Quaternary Paleoceanography of the mid- to outer continental shelf, east Greenland, Arct. Alp. Res., 27, 352-363.
Wunsch, C. (2002), What is the thermohaline circulation?, Science, 298, 1179-1180.

C. Andersen and N. Koç, Norwegian Polar Institute, N-9296 Tromsø, Norway. (cathrine. andersen@npolar.no; nalan.koc@npolar.no)

J. T. Andrews and A. Jennings, INSTAAR and Department of Geological Sciences, Box 450, University of Colorado, Boulder CO 80309, USA. (andrews@spot.colorado.edu; jenninga@ spot.colorado.edu) 